\title{
THE UNREAL WAR: THE INDONESIAN REVOLUTION THROUGH THE EYES OF DUTCH NOVELISTS AND REPORTERS'
}

\section{Tessel Pollmann}

How is it possible that for a long time the attempt to reclaim the Netherlands Indies after World War II has been described in Dutch popular books and magazines as a mission of mercy? This question obviously defies a simple answer. The timehonored history of the Netherlands' policy of neutrality as the leading factor in Dutch foreign policy is an element undergirding the common Dutch belief that "we" don't start wars. The Pax Neerlandica-that concept which Dutch teachers used to cite when explaining the conquest of the "Buitengewesten" to their pupils-is a related element. The atmosphere in the Netherlands during the years 1945-1950 also explains the fairytale-like depiction of the rather savage war-efforts in the Netherlands-Indies. The belief, widespread in the Netherlands, that the Javanese are obedient and docile $(\mathrm{kalm}, \text { gedwee, volgzaam })^{2}$ played a significant role. All of these features permeated the thoughts and feelings with which the Dutch were brought up, shaping attitudes which were then shattered in the late sixties and the seventies.

So the volunteers, the professional military and the conscripted soldiers who served in the Netherlands Indies during the period 1945-1950, came from a

\footnotetext{
${ }^{1}$ Dr. Frances Gouda kindly translated this article from Dutch into English. A much longer version of this article appeared in: Linden, M. van der en Mergner, G: Kriegsbegeiserung und mentale Kriegsvorbereitung (Berlin, 1991). This article will appear in: T. Pollmann, Bruidstraantjes en andere Indische geschiedenissen ('s Gravenhage: SDU, 1999).

2 T. J. Bezemer, Beknopte Encyclopaedie van Nederlands Oost-Indië ('s Gravenhage: Martinus Nijhoff, 1921), p. 212.
} 
background which did not help them clearly see what was happening in the Netherlands-Indies. The information they received from the army was little help. ${ }^{3}$ The civil population in the Netherlands did not get a very clear picture of the situation either; during the first years of the Revolution, the majority held to the conviction that Sukarno's government was a collaborator with the Japanese and that the Revolution was the work a small group of ringleaders and terrorists (raddraaiers en extremisten) who lacked popular support.

In fact, most believed that the normal "tani" (farmer) and "coolie" in Indonesia wanted the Dutch back, and that it was the mission of the Dutch to bring rust en orde (which doesn't mean "peace and order," but rather "control and order") to their colony. "We know this in part because a number of soldiers and officers who served in the Indies during the late forties have described their impressions and emotions in novels that appeared during the late 1940s and the early 1950s. In addition, Dutch journalists published their newspaper reports in books which appeared in the late forties and early fifties. And series of (over-edited) diaries have appeared that touch upon the themes described above. This range of commemorative volumes, which saw the light of day during, or just after, the Revolution, provides insight into the mentality which shaped the Dutch national myth defining the Dutch army as a sort of Peace Corps.

Provided we acknowledge the constraints of such historical sources, all the novels, memoirs, and commemorative volumes illuminate a perspective on a world which made it possible to represent an extremely aggressive war as a "police action" devoted to the poor and the powerless.

To understand this perspective we must first go back to the Netherlands in 1945. It was a special year: the year of peace. On May 5, 1945, the Germans surrendered. There was joy and happiness. Peace forever, that's what the people wanted. They were passionate in their admiration for the Allied troops. The idea of an army, especially in 1945-1946, was best embodied in these nice Canadians who brought chocolate and cigarettes.

In August Sukarno proclaimed the Revolution. Only the Dutch minority who had relatives and friends in the Netherlands-Indies was alarmed. Most people thought the Revolution would blow over. No one suspected that a new war might be coming, and surely not in "our" Indies. The Cold War had not yet started. In addition, "we," the Dutch, were no war-mongers. Except for the conquest of the Buitengewesten, we had not started a war since the ten-days' war with Belgium in the 1830s. The Java-war doesn't count; it has no place in the collective memory.

Yet though "we" didn't like wars, "we" acknowledged that something had to be done about the Japanese who in the spring and summer of 1945 were still in control of the Netherlands-Indies. And so twenty thousand Dutch volunteers were trained;

\footnotetext{
3 See L. de Jong, Het Koninkrijk der Nederlanden in de Tweede Wereldoorlog, vol. 12 (Leiden: Martinus Nijhoff, 1988). J. Bank, ed., De Excessennota, nota betreffende het archiefonderzoek naar de gegevens omtrent excessen in Indonesie begaan door Nederlandse militairen in de periode 1945-1950 (Den Haag: SDU, 1995), p. 159. G. M. Rossum, Groen is de oetan (Leiden: J. J. Groen \& Zoon N. V., [Na 1947]).

4 J. A. A. Doorn and W. J. van en Hendrix, Het Nederlands Indonesisch Conflict; ontsporing van geweld (Amsterdam: De Bataafsche Leeuw, 1983), pp. $124 \mathrm{ff}$.
} 
between September 1945 and April 1946, fifteen thousand of them were shipped to Southeast Asia. ${ }^{5}$ They didn't go to Indonesia straight away. They were first concentrated on Malacca, where they were housed in dirty, neglected barracks that had been used previously by the Japanese. Here the volunteers were trained for fighting in tropical areas by British officers and officers of the KNIL (the Royal Netherlands Indonesian Army). The troops were eager to advance to the Netherlands-Indies, but were prevented, and thus frustrated. The British had taken charge of the training and of the situation in the Netherlands-Indies. It made the volunteers impatient and angry. It was March-April 1946 before the first Dutch troops reached Java.

Most of the volunteers were young. Some of them were resistance-fighters. All of them had been confined to the Netherlands for five years during a time when no voyages or holidays abroad were possible. They anticipated their trip to the colony as an exciting adventure.

However, the Japanese had already surrendered on August 15, 1945.

But the Japanese camps where most of the Europeans residing in the Indies were interned during the war years 1942-1945 have still to be liberated. Here is a job to accomplish. Soon another mission emerges as well: the suppression of Sukarno's supporters. From the Dutch perspective, however, mobilization against Sukarno's supporters did not qualify as a new war. Dutch civilians wouldn't accept the start of a new war just after the end of World War II. So the efforts of the Dutch army to subdue these revolutionaries were presented to Dutch civilians, to volunteers, and to conscripts as a mission of mercy-a kind of Peace Corps mission, accompanied, alas, by a few police actions. Till the end of the Revolution, in December 1949, the official Dutch action in Indonesia is described as the suppression of internal unrest, as a difficult task pursued in the interests of the peace-loving coolie and tani whom the Indonesian nationalists misrepresent and oppress. That's the way politicians and professional soldiers "sell" the war. General Spoor for example tells his men on July 1947: "You've not come here to punish, but to protect, and those among you who in the last two years have lost relatives or friends by Indonesian elements incited to criminal behavior should never forget their self-control." 6

The Indonesians, however, had a different perspective on the situation. They did not see their struggle as a minor incident of "unrest" stirred up by a few criminals who had terrorized and intimidated the naive and innocent tani, but as a Revolution against the Dutch. For them it was a war between states, between the Netherlands and Indonesia. This definition of the conflict was ignored by the Dutch, who thereby created a situation which was difficult for the military to handle. Were they fighting a war, or intervening in an internal conflict? The Dutch were willing to believe that the Peace corps-option was honestly what politicians and professional soldiers had in mind: voters, parents, priests, politicians, officers, volunteers, and the numerous conscripts together pretended that sending a force of two hundred thousand military men to the Netherlands-Indies in 1945-1949 didn't mean there was a war.

\footnotetext{
${ }^{5}$ L. de Jong, Het Koninkrijk der Nederlanden in de Tweede Wereldoorlog, vol. 12, First Part (Leiden: Martinus Nijhoff, 1988), p. 755.
}

${ }^{6}$ J. Bank, ed., De Excessennota, p. 159. 
96 Tessel Pollmann

The two hundred thousand men who were being sent to the Netherlands-Indies consisted of twenty thousand volunteers, the corps of professional soldiers, and the many conscripts who were called up from April 1946 to the end.

Until 1949 the majority of the Netherlands population supported this action. Most civilians agreed with the politicians' view that the Pax Neerlandica had to be reestablished, and that after this was accomplished, then the Dutch colonial regime would be willing to open talks about the future. Hence, decolonization was perceived as a phenomenon whose schedule would be unilaterally determined by the Dutch, as it had always been. From the turn of the century, when the first clarion calls for Indonesia's independence resounded, the Indonesians (or "the inlanders" as they were called) were confronted with the perennial colonial argument that the Indonesian population was not yet "ripe" or mature enough to handle national sovereignty. The Netherlands colonial administration carefully guaranteed that this process of maturation would not occur too swiftly: although Dutch was the official language of the Netherlands-Indies, only a small percentage of the indigenous people were allowed to attend schools where Dutch was the first language. Until the 1920 s no institutions of higher learning existed in the Indonesian archipelago. When Dutch residents departed from Indonesia in 1950, they left behind only 350 university-trained Indonesians.

But how much of this was common knowledge among the average Dutch volunteers, professional military officials, and conscripted soldiers who departed for the Dutch East Indies in the period 1945-1950? Very little. Most people in the Netherlands were ignorant about the kinds of colonial relationships that prevailed in the Netherlands Indies; they were also unaware of the intricacies of the process of decolonization. In the Netherlands, people who had repatriated from the Indies just before World War II (or who were on home leave when the war broke out) traditionally functioned separately and apart from the "normal" Dutch population. The circle of excolonial residents belonged mostly to the elite, because it was not necessary to attract Dutch manual laborers or vocational workers to the Netherlands Indies. This elite didn't communicate with the Dutch lower and lower-middle classes, and in 1945-1949 most military men came from these humbler classes.

Missionaries, who had worked and taught in the Netherlands Indies before World War II and expressed their views about the colonial situation in sermons and religious instruction, also belonged to the elite. And the elite was conservative, very conservative, and often not aware of what was going on in the hearts and minds of the "inlanders." How could such an elite prepare the soldiers for their assignments in the East Indies? They couldn't.

So the average drafted soldier did not know much of anything about the Indies beyond what he had been told in school or church. This was woefully little. As late as 1950, when many Indo-Europeans repatriated to the Netherlands, many Dutch folks asked them whether the Indonesians had lived in trees or how they had managed to learn the Dutch language. That highly innovative technologies had been implemented in oil refineries and the sugar industry, or that trains crisscrossed the Indies and trams provided public transportation in cities revealing modernist, avant-garde architecture, were facts unknown to most Dutch citizens. 
In addition, the limited pre-war knowledge of the colonies that circulated within Dutch national culture, deep in the European heartland, was rendered obsolete during the five-year Nazi occupation. During World War II a number of changes had occurred in the East Indies, unbeknownst to most Dutch citizens. Initially, the Indonesian population had joyfully welcomed the arrival of the Japanese in March 1942 with the slogan "Asia for Asians." This sense of shared victory and alliance had diminished during the Japanese occupation, but what had not disappeared was the Indonesian people's awareness that public life in their country could function reasonably without the assistance of Dutch colonial civil servants. All sorts of public-sector positions that had been the prerogative of white-skinned Dutch residents prior to World War II had been more or less successfully filled by Indonesians in subsequent years, and these new officials were not inclined to vacate their posts on behalf of Dutch civil servants once the Japanese occupation ended. Besides, the Japanese had contributed to the growing sense of nationalism in other ways. In exchange for political support during the war, officials of the Japanese regime had given nationalist leaders such as Sukarno and Hatta substantial leverage and freedom. Nationalism, as a result, transcended its prewar dimensions, so that it was no longer confined to the domain of urban intellectuals. Nationalist propaganda saturated the kampung and affected especially younger Indonesians. Few people in the Netherlands could know about this development. And when in late 1945 and the years thereafter more information about these developments reached the Netherlands, few were willing to lend it any credence. Instead, the imagery that conscripted Dutch soldiers carried with them to the Indies was a perception of poverty-stricken, demoralized Indonesian peasants eagerly waiting to be rescued by young Dutch knights in shining armor. And it is this image that we encounter in the novels written by volunteers and conscripted soldiers soon after the Indonesian Revolution.

One of those novels is called Groen is de oetan (Green is the utan). ${ }^{7}$ An otherwise unknown writer named G. M. van Rossum wrote the book after 1947. It is a book which obviously contains autobiographical elements. As is the case with other examples of this genre, the novel opens with a description of the journey from the Netherlands to the Dutch East Indies as it was experienced by the young soldiers on board ship. Adventurous feelings inspire them.

The feelings of adventure and of romanticism were not limited to the long sea voyage; in these war-novels many soldiers are depicted as being excited about the chance to serve in the Dutch East Indies, in an exotic country. That is where they are going to perform their good deeds, as the colonel tells the troops: "Men, you have come this far in order to accomplish a difficult and onerous task, but one that is also an honorable duty. I understand all the difficulties that being separated from your home and being in this tropical land may cause you, but be tough. Be alert and diligent and trust in God, then everything will be all right." 8

What is most striking in this passage is the non-military character of the task ahead, as it is described by the colonel: the soldiers will be undertaking an "honorable

\footnotetext{
7 Rossum, Groen is de oetan.

${ }^{8}$ Ibid., pp. 7-8.
} 
duty." A Peace Corps duty. And lieutenant Vermeulen, the main character in the novel, believes this characterization.

This idealistic Peace Corps mission however has its ideological critics, and G. M. van Rossum describes them aptly. First, the reader meets the radical leftist comrade Nelis de Wit, alias the Grouch, who makes his diagnosis of their mission one day after his arrival in Java: "If the entire rotten capitalist clique of yours gets its chance, they will once again exploit the Indonesians for a nickel and a dime. And we have to muck around in this mess for two years while being forced to fight against people we have never seen." ${ }^{\prime \prime}$

The Grouch's words create a tension that is only broken by the sudden entry of an enemy bullet. "Do you have more such friends, Nelis?" another soldier asks laconically, registering his objection to Nelis's diagnosis. He objects not so much because he is sure that Nelis's critique is incorrect, but because Nelis's views are shared by the enemy and should therefore remain unspoken. ${ }^{10}$ As happens with many of the socialist and communist characters who people this literary genre, Nelis quickly abandons his ideological complaints and adopts the views of his fellow soldiers: Dutch troops fight for the little people of Indonesia and not for the well-fed whiteskinned capitalist or civil servant. The same theme returns on page 124 of Groen is de oetan, when the battalion of Lieutenant Vermeulen, Nelis de Wit, and Major Hoogland deliver a group of captured terrorists to the local prison. A white civil servant, who hails from the pre-war colonial elite, welcomes them. In a conversation the civil servant reminisces about a restaurant in a particular kampung: " . . where, he noted while rubbing his fat beefy hands, before the war one could eat the best steak in the entire district at Tang Eng An in Kampoeng Mesjied. 'When do you think our troops will get there?' Hoogland looks at him sharply. Fat pig, he thinks. That is the reason why we have to risk our lives, so that you can eat your steak again-ridiculous man with your big hat and hands like sausages."11

The focus of the Dutch troops in this novel is a simple one: Dutch troops do not come to the Netherlands Indies to accommodate the pre-war colonialists. Colonialists are elite. The troops consist of people from all classes, and many of the volunteers and conscripts were brought up with a healthy mistrust of the upper classes. In these novels, the troops' mistrust of the elite often extends to include the officers of the Royal Netherlands Indies Army (KNIL), whose members were part of colonial society and for whom authoritarian behavior is second nature. In these novels, the well-fed civil servants and especially ostentatious planters are a constant target of derision. These colonialists reside outside the bonds of solidarity that unite regular Dutch boys who were drafted into the Army and have come to help the small peasant, the victim of the terrorists and extremists who belong to the nationalist movement.

The alliance between the Dutch soldier and the small tani is the ideological thread that ties together many of these novels, and in Groen is de oetan this is distinctly the case. Towards the end of the novel Lieutenant Vermeulen's battalion seizes a kampung in Republican territory where they encounter two terrorists. These two are shot in

\footnotetext{
${ }^{9}$ Ibid., p. 11.

${ }^{10}$ Ibid.

11 Ibid., p. 124
} 
orderly fashion without harming the civilian population. This tidy process contradicts the rumors in the Netherlands (which were often grounded in the truth) that the Dutch military was inclined to burn down an entire village if and when the troops suspected it might harbor a terrorist. But in Groen is de oetan Dutch soldiers never pillage kampungs. On the contrary, they liberate them. After the two terrorists had been killed, ". . . skeleton-like figures emerge from all the nooks and crannies of the village. Men, women, and children. Covered with sores, exhausted by malaria, shriveled and skeleton-like in appearance. And everyone shouts at the same time: can we come with you, Toean? We want to leave, toean, can we go elsewhere, toean?"12 This general plea by the peasants to be evacuated from Republican territory is followed by fifteen pages of text in which the evacuation actually takes place. In these pages, the emphasis is on the racial equality between the Dutch soldier and the Indonesian tani. In a folksy manner one Dutch soldier says, pointing at one of the little children, " . . look at that little tyke: if the child did not have such a brown skin and was not covered with sores one could swear it would be the little one [annakie] of my sister."13 At the same time he distributes the peppermints that he has received from his mother in the Netherlands among all the children present. The sturdy battalion of Lieutenant Vermeulen, meanwhile, guides the group of haggard, ill, and poverty-stricken adults to safer regions; one of the Dutch soldiers assists in the delivery of a newborn child during the journey. In the course of the evacuation the troops find themselves short on drinking water, and when one soldier asks his buddy for a last drink of water he responds: "Sorry, man, I gave it all to the children."14

At long last the exhausted battalion and the thousand evacuated villagers arrive at the military post where the colonel awaits them. He addresses them with praise:

Men, I'll be short. Today you have accomplished good work under the direction of your commander. I just heard it did not proceed smoothly but you managed to fix it. Later you and I will remember this occasion when we read how Dutch newspapers portray us as sadists and arsonists of kampungs. When hearing such things, don't grit your teeth but simply recall the image of these people whom you have liberated, then the satisfaction of this good deed will compensate for the calumny of penpushers over there. ${ }^{15}$

The theme of this particular novel focuses on solidarity that unites not only the soldiers themselves, but also the Dutch officers, volunteers, and enlisted men. This theme resurfaces again towards the end of the novel. On the last page Corporal Hartjesveld is carried to his grave. In the funeral scene the relationship between a good officer and his men is characterized as paternal, reiterating a father-son motif that has appeared before. Without being invited to do so, soldier Barend Smallegange steps forward as the coffin descends into the grave, and he talks with the courage of a child:

"I know it is not customary that a simple soldier like me speaks at a funeral," Barend says, "but we all stand here at the grave of our corporal as comrades, and I have something to say. We have said to each other that a corporal such as

\footnotetext{
12 Ibid., p. 211.

13 Ibid., p. 213.

14 Ibid., p. 214.

15 Ibid., p. 224.
} 
100 Tessel Pollmann

this one we will never find again, and we mean it. Because he has cared for us as a father, and he was always patient with us when we were disobedient. Now he will no longer guide us on patrol but it will appear as if he is still with us. On behalf of the boys in our group I therefore want to say: Corporal Hartjesveld rest in peace." 16

What becomes clear in this passage is a general denial that the army is an army and that this war is a war. To whom are these denials addressed? To the homefront where critics, talking at home or in the barbershop or sometimes writing in the newspapers, mutter about the excesses (or war crimes) which have been reported through letters and rumors, and about reports of the number of wounded and killed Dutch men.

Critics of the war effort were not all fictional. We note the publication of a letter by Captain Zweeres in the leftist weekly De Groene Amsterdammer, issue dated February 25,1949 . In this letter the captain depicts Dutch army "excesses." 17 His report indicates that not everything was well.

Such reports and rumors had to be denied. One of the ways to deny them was to manipulate the press. That was not too difficult, since without the cooperation of the army, a journalist couldn't go into the field. Many journalists didn't even press for permission to go into the field. The reporters, most of them young and inexperienced, generally believed and reported what the army told them. And the army itself had reporters, military p.r. men who wrote statements which were used by nearly all the newspapers. What tension there is-and there is tension-doesn't exist between aggressive journalists and military officers who, by profession, lie to journalists, but between journalists and officers on the one hand and politicians on the other hand. The politicians spoil the game: they negotiate while the soldiers fight and they come to an agreement at exactly the moment when the military goal is nearly reached..$^{18}$

The typical Dutch journalistic ${ }^{19}$ approach to the Revolution can be found in the accounts written by Willem van der Pol, collected in his book Kerels van de daad (Fellow in action) which was published in 1947. In this book Van der Pol places on center stage a young man who wonders why more Dutchmen didn't volunteer for military service in the Dutch East Indies:

I'm sure that if they could sit here and see the same mess and misery we encounter daily, then they would eagerly volunteer. Of course there are always weaklings who only want to go to the movies or stand on the streetcorner at night with black [author's note: selling things on the black market.] But let's imagine that the Canadians had viewed it in this way, too. They were also volunteers, weren't they? And is the situation here any different? I don't care about politics, but would this be a reason to let people die here? If I may I will bring you to a place in a neighborhood nearby where emaciated people are dying in the stinking

\footnotetext{
${ }^{16}$ Ibid., p. 239.

17 T. Pollmann, "Ko Zweeres, dissident tegen wil en dank," in Bruidstraantjes en andere Indische geschiendenissen ('s Gravenhage: SDU, 1999), p. 125.

${ }^{18}$ T. Pollmann, "Oorlogsmisdaad of exces," in Ibid., p. 104.

${ }^{19}$ H. Verstraaten, “De oorlogsverslaggevers van 1947," Vrij Nederland, July 5, 1980.
} 
mud because they don't dare to run away. Perhaps we'll reach them in few days so we can rescue them and bring them to a safer place. But now they don't even dare to eat with you because they know they sign their own death sentence if they do so. 20

A similar theme preoccupies a collection of reports written by J. W. Hofwijk in 1947 entitled De Hitte van de dag: onze soldaten in Indië (In the Heat of the Day: Our Soldiers in the Indies). ${ }^{21}$ Hofwijk was a reporter for de Maasbode, a newspaper that was the medium for the Catholic middle class and the Catholic People's Party. The Catholic People's Party pursued such a very conservative policy vis-à-vis Indonesia that it could hardly be kept in check by the waffling social-democratic Labor Party in a sequence of government coalitions. But in the opinion of the Army commanders stationed in Batavia itself, both the hesitant policies of the social democrats and the quite conservative views of the Catholic Party were too feeble. The man who best embodied the Army command's attitudes and furthered its efforts to acquire more power and leeway was the Commander-in-Chief and Head of the War Department in the Netherlands Indies, General Hendrik Simon Spoor, a leader both admired by Hofwijk and glorified by Van Rossum in Groen is de oetan.

As a war correspondent Hofwijk could file his reports only with the permission of the Military Information Service in Batavia, which supervised his transportation and monitored his contacts with the troops. Hofwijk, in turn, fulfilled their needs and followed their directions. Judged by Hofwijk's reports, never before had a more generous, joyous, and honorable military force struggled for such a good cause. Our boys in the Netherlands Indies were pursuing a noble struggle, perhaps even a war. But if it was a war, it was an honorable war.

Yet Hofwijk's descriptions of what these actions really entailed exposed an underlying ambivalence toward war itself: "From my perspective war revolves around fear and death and loneliness. It consists of camaraderie, courage, and the yearning to stay alive. War involves uncertainty and exhaustion and also hatred, doubt, and rumor. But its dominant feature is blood and sweat and solitude." 22 But he did not allow himself to express ambivalence about the noble qualities and honorable goals and methods of the Dutch forces. Their war did not rely on aggression and was not offensive. Hofwijk's portrayal of the Netherlands Army's colonial war was modeled on similar portrayals of war waged by the Allied liberation army; these efforts did not resemble acts of aggression carried out by the occupation forces of Germany and Japan. Accordingly, in Hofwijk's kind of war nothing happens that is not dedicated to helping the poor, innocent, and apolitical Indonesians who are being threatened by a bunch of politically obsessed countrymen. Political action, after all, is the God-given privilege of white-skinned residents who have functioned as caretakers and executives of the "White Man's Burden," who have nurtured and governed their little brown brothers because the latter were not yet mature enough for such political activities. This is the political and military message that Hofwijk delivers to his readers in his

20 Willem van de Pol, Kerels van de Daad ('s Gravenhage: W. van Hoeve, 1947), see chapter: "On Java." (The pages of the book are not numbered.)

${ }^{21} \mathrm{~J}$. W. Hofwijk, Dit hitte van de dag;onze soldaten in Indonesië (Heemstede: De Toorts, 1947).

22 Ibid., p. 8. 
102 Tessel Pollmann

attempts to convert them from any impression that the war entailed not only a fight between armies, but also rape, pillage, torture, and the killing of innocent civilians. Hofwijk deliberately corrects those who might have such views. He admiringly quotes a soldier who describes the homefront in the Netherlands this way: "I hope they are bold enough to shout 'murderer' when we return! That will be quite a happening. If only those poor devils could visit a kampung we supposedly suppress. The villagers who live there will teach them to see it differently. The people in the kampung like us much better than many of our compatriots in the Netherlands." 23 Another soldier proclaims: "I have the feeling we have to fight on two fronts. And when you find yourself in a trading post or a kampung and you are up to your ears in difficulties and you feel quite lonely, then nothing is more miserable than knowing that people in Holland are not really backing you either." 24

Clearly this is an odd kind of war. Its peculiarity was that the Dutch Army in the Indies had to protect itself against the very same mother country that had commissioned it: the Kingdom of the Netherlands. Defenses had to be mobilized on two fronts: in the arena of politics and the domain of public opinion. It becomes evident in these journalistic accounts that a political tension existed between the military command in Batavia, which routinely demanded that the government in the Netherlands support a tougher military action, and politicians in The Hague, who had to maneuver carefully because the Dutch electorate had mandated police actions, but not all-out war.

In 1945-49, enthusiasm for "aggressive" war is alien to the average Dutch citizen. Yet a curious enthusiasm for performing good deeds-these good deeds must be imposed on the poor and the oppressed, if necessary-informs popular Dutch ideology at that moment. No country in Europe produced as many Catholic and Protestant missionaries in 1946. Hofwijk himself was a reporter for a Catholic newspaper which, like most newspapers, was obedient to the civil authorities. In an article published in the weekly Vrij Nederland, one officer commented on the fact that during the German occupation, when so many Dutch men were imprisoned, obedience had grown into a normal habit of everyday life. ${ }^{25}$ Critical journalism was rare. Only the daily newspapers Het Parool and De Waarheid and the weeklies De Groene Amsterdammer and Vrij Nederland were critical. The rest were docile. Five years of occupation by the Germans had left behind not only an anti-war atmosphere, but also a very obedient press. The slightest criticism was offensive.

As far as obedience was concerned, Hofwijk put out his best effort. He wrote, for instance, that scorched earth tactics were applied solely by the enemy and not by the Netherlands Army, even though he should have known better. ${ }^{26}$ Also, he claimed that the Army's mentality was not at all colonialist: describing " . . armed tourist groups," as the mobile troops once called themselves, Hofwijk asserted that " . . it could not

\footnotetext{
23 Ibid., p. 19.

24 Ibid.

25 T. Pollmann, Bruidstraantjes en andere Indische geschiedenissen (Den Haag: SDU, 1999), p. 116.

26 Hofwijk, Dit hitte van de dag;onze soldaten in Indonesië, p. 31.
} 
be less colonial."27 Hofwijk quotes senior officers repeating this exact same sentiment when they declare sarcastically:

After all, we are colonialists, and when we attack it is purely to oppress the Indonesians . . . But in the kampungs people don't believe this, and when the villagers who have fled their burning houses, hear about this, they don't accept this either. And the loerahs [village head] don't believe it either. However, they can't say so openly because then they are kidnapped soon thereafter. Only people who live 14,000 kilometers away from here scream that we commit murder and mayhem. 28

Under no circumstances should the struggle in the Dutch East Indies be called a colonial war; we have noted this point before. In Hofwijk's reports, which were widely read, the Army's attitude toward the Indies is clearly distinguished from the attitudes of pre-war colonial civil servants and businessmen. A lieutenant who appears in Hofwijk's reports articulates this point succinctly:

Real colonialists still exist here. If one talks with some of the old Indies hands they constantly blame us for not keeping the natives at enough distance: they say we shouldn't oppress them but we are blanda [Dutch], after all, and those natives have little sense of measure-when we offer them a finger, they ended up taking our whole hand. If we treat them as equals they interpret it as weakness. But I don't like this at all. They are people just like us and although I could be wrong I choose to treat them as I would anyone else. ${ }^{29}$

The distance separating the conscripted Dutch soldiers who are simply fulfilling their service (Hofwijk calls them the best democrats) from the supercilious pre-war colonial residents is larger than life. This theme emerges in many novels and journalistic accounts about the revolutionary years. This conflict between different Dutch perceptions of the Indies, and of its people, forces run-of-the-mill soldier conscripts and many of their officers to confront difficult questions daily. On whose behalf are they fighting? Are they struggling for democracy in the midst of a people who are "just like us"? Or is their service dedicated to the accommodation of those old Dutch Indies colonialists, those "fat pigs"? A lack of political insight, compounded by an absence of public information, newspapers, education, and personal political experience, all contributed to a general feeling of emptiness shared by many of the non-professional combatants. These soldiers posed the essential question: why all the efforts and all the suffering? Even Hofwijk, despite his optimistic assessment of the morality of "our boys" in the Indies, can't resolve this question. He can't ignore evidence that the average soldier feels like a dumb foot soldier and/or cannon fodder, and so he comments on it. As always, however, he imbues this observation with a glow of idealism and admiration. But I do not think Hofwijk fully convinces his readers when he emphasizes how proud he is " ... of our own people, about being Dutch, when I see our soldiers here in their daily toil ... sweaty and exhausted and completely broken at times from slaving, struggling, and exerting themselves in this honest work which is

\footnotetext{
27 Ibid., p. 43.

28 Ibid., p. 95.

${ }^{29}$ Tbid., p. 168.
} 
104 Tessel Pollmann

difficult to grasp and which many can't fathom completely, but which they accomplish nonetheless. They simply do their work." 30

"They," soldier and officer, wonder why they are here, in the Indies, in this world full of contradictions.

The contradictions are very clearly portrayed by the medical soldier A. van Helvoort who described his term of services in the Dutch East Indies in a book called De verzwegen oorlog: dagboek van een hospik (The Silenced War: Diary of a Medic). ${ }^{31} \mathrm{His}$ account is striking. As a medic he was directly confronted by the ironies of this war that sent Dutch soldiers against their Republican opposition in a faraway country that was not, by law, foreign. Indonesia was still part of the Kingdom of the Netherlands, which meant that even rebellious Indonesians, "terrorists," were entitled to Dutch medical care. And often Indonesian nationalist "terrorists" received such treatment. This is an astounding discovery to the medic. He asks who in his right mind would treat his enemy in such a way that when he is released from the hospital he can immediately rejoin the attack? Equally astonishing to Van Helvoort is the Dutch handling of Republican prisoners of war, "thousands" of whom are not killed but are " ... treated nicely, given food and drink and sometimes furnished with clothing, only to be returned to Republican territory from where they resume their assault on Dutch troops. Dutch boys who have been captured by the enemy rarely reemerge alive. And if they are recovered, they are either dead or seriously disfigured." Such inequities lead to war crimes, Van Helvoort continues, describing these crimes with the word "excesses" as was customary during this era:

... the boys in the infantry regiment 2-5 RI are deeply engaged in excesses because they are difficult to avoid. I can imagine acutely that when people from the kampung shoot at you, you want to return fire and aim at everything that seems to move. So mothers and children have been fired at. But those mothers and boys of fourteen or fifteen years old were carrying weapons and were shooting at our boys. In those circumstances shouldn't our boys be allowed to fire in response? ${ }^{32}$

The schizophrenia of this war was bewildering to the majority of the Dutch military. On the one hand, the war was supposed to represent a mission of mercy, and indeed occasional acts of mercy were carried out. On the other hand, the conflict constituted a full-fledged guerrilla war that made it difficult to differentiate between Republican guerrilla fighters and regular farmers. One day Dutch soldiers nurtured and took care of an emaciated child, or they inoculated residents against the plague; the next day these friendly, smiling, grateful, and apparently apolitical souls changed face and proved to be The Enemy. In retrospect, many Dutchmen came to the conclusion that those villagers were not as pro-Dutch as they pretended to be. During the period 1945-50, however, the explanation used to explain these transformations was that the simple peasant in the countryside was forced to participate in the guerrilla war,

${ }^{30}$ Ibid., p. 16.

31 A. van Helvoort, De verzwegen oorlog. Dagboek van een hospik in Indië 1947-1950 (Groningen: Xeno, 1988).

32 Ibid., pp. 62-63. 
whether or not he wanted to, by terrorist compatriots. The Republican terrorists or extremists were described as

... the military men dressed in civilian clothing who don't dare to engage in an open fight but are good at employing the guerrilla tactics they learned from the Japanese; peloppers [revolutionaries] who one moment will work in the fields as friendly and deferential tani, but who the next moment will grab a weapon from the ditch in order to shoot at you; those are the men who terrorize and murder their own people and blame the Dutch for their grievous acts. ${ }^{33}$

This sort of rhetoric generates a climate of self-pity. And the climate, in this context, is intensified literally by the sultry heat and the jungle in which guerrilla warfare could thrive and against which the barely trained Dutch conscripts had few defenses except their possession of a superior store of weapons and ammunition. Dutch military of all ranks-volunteers, conscripts and career officers-felt misunderstood and abandoned. They were limited in their actions by the Dutch government, which provided them with weapons, but also with bad food, shoddy clothing, and poor salaries (the Dutch economy hadn't yet recovered from the German occupation). They were fighting in a war that was not supposed to be a real war, but which was nevertheless made up of gruesome battles. The brutal ugliness of the guerrilla war was ignored by Dutch colonial residents and especially by the resident Dutch women, who only wanted to dance with the officers ("the fawning of those women was a horrible sight"). This continued while soldiers kept up the struggle that had been officially mounted on behalf of the brown-skinned villagers-villagers who so often proved ready to fight on the side of the Republic, whether or not they were pressured into it. In this climate of denial and self-pity one tends to deny reality and to create myths, such as the legend that every Indonesian prisoner of war was well treated by his Dutch captors, even if in reality many of these prisoners were killed. This self-pity echoes in the titles of books written by veterans-veterans can be conscripts, volunteers, or career officers-titles like Thank you very much, gentlemen. The forgotten army in the Indies, 1949-1950.34 The bitterness in these titles reflects the anger of those who felt betrayed by their own politicians.

After years of fighting and suffering the Dutch army was forced in December 1949 to lay down its arms at once because the Netherlands had caved in to international pressure and relinquished sovereignty to the Indonesian Republic, an act which many veterans viewed as a display of political cowardice. Equally difficult to accept was the fact that the only subsequent long-term military option was retreat; even today many of the volunteers deny the military superiority of the Indonesians and insist that the Dutch could have won the war.

For the most part, the veterans' sentiments of rancor and self-pity roused little response in the Netherlands. The leading politicians from the period 1945 to 1950 simply remained in place after the war was lost. Because the loss of the Netherlands Indies did not precipitate an economic disaster, the Dutch accepted it passively. Little interest was kindled by the personal and social problems of the veterans. In like

${ }^{33}$ Ibid., p. 62.

34 Anton de Graaff, De heren worden bedankt, met het vergeten leger in Indië (Franeker: Van Wijnen, 1986). 
106 Tessel Pollmann

manner, only the smallest amount of public concern could be mustered for the catastrophic damage wreaked on Indonesia itself, damage measured both in terms of lost human lives and devastated social conditions. Two decades later, during the fervent international protests against the American intervention in Vietnam, even the few volatile Dutch citizens still left in the country rarely noted the analogy between America's misguided conflict and their own country's "pacification" efforts in the Netherlands Indies.

In 1969 there was a turn. The psychologist Hueting presented on TV his version of the Dutch mission of mercy: he acknowledged that he had mistreated people and that he regretted it. What everybody knew now came out. The government ordered a study which was published as the Excesssennota. Van Doorn and Hendrix, soldiers and comrades in 1945-1950, now a professor and a researcher, respectively, analyzed the reports of atrocities that were now unearthed. Veterans complained that the media exposure that followed this research was very unfair. Yet it was not done in order to redefine the period $1945-1950$ as a time of war.

As the atrocities, "excesses" or "war crimes," were being researched and exposed, a widespread nostalgia for life in the colonies began to flourish in the Netherlands; stores displayed books with glossy pictures of white people in tropical dress lounging beneath the beautiful palm trees. Any book focusing on the post-war history of Indonesia found and finds no buyers. Revelations about the war crimes committed by "our boys" overseas are now generally perceived as legitimate. But as a nation we don't conceive of ourselves as any less (or more) pacifist than we were in 1945-1950. After all, there was no war. Not a real one. 